\title{
FOOD SUPPLY CHAIN INTEGRATION: LEARNING FROM THE SUPPLY CHAIN SUPERPOWER
}

\author{
IntanMarzitaSaidon $^{1}$, Rafisah Mat Radzi ${ }^{2}$ and Nadzri Ab Ghani ${ }^{3}$ \\ ${ }^{1}$ Faculty of Accountancy, UniversitiTeknologi MARA (UiTM) Kedah, Malaysia \\ ${ }^{2}$ School of Distance Education, UniversitiSains Malaysia, Malaysia \\ ${ }^{3}$ Faculty of Accountancy, UniversitiTeknologi MARA (UiTM) Kedah, Malaysia
}

\begin{abstract}
Supply chain integration is postulated as the key to achieve supply chain management excellence. There is an equivocal claim that Japanese companies are better at managing their supply chains. Yet, little is known about the Japanese food supply chain. Ten interviews with supply chain managers were conducted using an open ended interview approach. These companies were randomly selected based on Japan External Trade Organizations (JETRO) listing. Using a qualitative approach, the findings indicate that a short and simple structure is a platform of the food supply chain. Furthermore, the companies extremely interface with suppliers of raw materials (backward integration) and seriously concern about coordinating and integrating cross functional processes within the companies (internal integration). In addition, these companies portray to have a moderate level of integration with their customers (forward integration). Finally, the Japanese management styles appear to be a pivotal supporting element in managing the integrated food supply chain.
\end{abstract}

\section{KEYWORDS}

Food Supply Chain, Supply Chain Integration, Japanese Companies, Malaysia, Supply Chain Management

\section{INTRODUCTION}

Stevens[1]defined supply chain integration as the mutual coordination within or across organizational boundaries. More specifically, supply chain integration involves the collaboration of tactical, operational and strategic level activities of the companies in the chain[2]. Supply chain integration is posited by many researchers as a key to achieve supply chain management excellence [3, 4]. A well integrated supply chain may help companies to experience a seamless flow of receiving raw materials from suppliers till delivering the final products to customers. Thus, companies' performance would be improved through revenue enhancement, cost reduction and increase operational flexibility [5].

Although creating value to the end customers is the common objective of having a good supply chain for every company[6, 7], each supply chain may vary greatly from one industry to another [8]. The vulnerability of food supply chain is greater compared to other industry due to the nature of food products which are sensitive to temperature and deteriorate easily. Thus, having an efficient and effective supply chain is not an option for the food manufacturers. Any breakdown in the food supply chain such as contaminations would bring about serious consequences endangering both consumers and company image.

DOI: 10.5121/ijmvsc.2015.6401 
In researching the topic, the evidence suggests that existing studies in the area of food supply chain integration are limited. First, a substantial amount of supply chain research was done under positivist ontology applying a quantitative methodology. For example, 50 percent of the articles published in the Journal of Business Logistics between 1978 and 1993 employed survey method [9]. Second, the majority of published research in supply chain integration investigates the relationship between integration and performance, e.g. [10, 11]. Third, many previous studies in the stream choose to investigate a specific factor in the integration such as the use of information technology (IT), e.g. [12, 13]. Finally, most of the previous studies use data from the western countries, e.g. $[14,15]$, thus, limits the understanding of food supply chain in the western context.

Without doubt, these previous researches help to enhance understanding of food supply chain but their contributions are still limited. Acknowledging these limitations, this study aims to make four contributions to the literature. First, this study employs an alternative research methods by employing a qualitative methodology in analyzing the data. Second, as most of the previous research was based on the western context, this study expands the frontier by utilizing data from Malaysia, a country located in the South East Asia region. Third, although Japan is claimed to be a supply chain superpower[16], little is known about their food supply chain integration. Therefore, this study is deemed necessary to fill this gap. Finally, supply chain integration research is generally heavily weighted towards investigating a relationship with firm performance. In contrast, this study attempts to strengthen the basic understanding of food supply chain integration by exploring the integration practices employed by the Japanese food and beverage companies.

This paper is structured as follows. The following section provides a brief review of literature, including rationales of choosing Japanese food and beverage companies. The research methodology employed is then described. Finally, the results of this study are presented and discussed. It is hoped that the findings of this study will enhance understanding about Japanese food supply chain integration and act as a source of reference to other domestic food manufacturers.

\section{LITERATURE REVIEW}

\subsection{Why Japanese food supply chain?}

The development of the food industry in the developing countries may be viewed as strategic in the sense of providing sources of revenue as well as generating employment. It has been claimed that food industry contributes about 10 to 30 percent of developing country's wealth and generates approximately 15 to 50 percent employment opportunities[17]. Moreover, the percentage of food processing exports escalate from 6.6 percent in 1991 to 10.6 percent in 2006; reflecting a significant contribution of the food industry to the economy of developing countries [18].

As for Malaysia, the food processing sector accounts for about 10 percent of manufacturing output[19]. This sector generates more than RM 13 billion annual export value which amounts to two-thirds of the total food exports in 2012[19]. In 2011, it was reported that Malaysia has a packaged food industry worth US $\$ 5$. 5 billion, which is forecasted to grow to US $\$ 5.9$ billion by 2016[20]. Realizing the significant contribution of the food industry to the Malaysian economy, the government sets an investment target of RM 24.6 billion in this industry[21].One of the aspirations of the government is to position Malaysia as a prime food producer and trader in Asian region as well as to becoming a center for international halal food [22]. 
In response to this call, food processing companies in Malaysia should find ways to gain better control over production, trade and distribution of their food products. For instance, extended storage duration may have a negative impact on the quality of the food products. Coordinating the business processes and working closely with the chain members would help to preserve the quality of food products. Apparently, having time efficient and good integration in the supply chain is mandatory for food processing companies.

Japanese food and beverage companies were chosen for several reasons. First, Japanese companies are well known and closely attached to the Just in Time (JIT) philosophy, and researchers argued that JIT is the basis of supply chain management [23]. Therefore, there is an equivocal claim that Japanese companies are better at managing their supply chains. Second, as a progressive islamic country, Malaysia is very concern about halal compliance in the production of food products. The Malaysian Halal Standard MS1500:2004 is established to provide general guidelines regarding the production, preparation, handling and storage of halal foods[24]. Halal certification provides assurance to the Muslim consumers that production of the food products conforms to the Syariah law. As for the non-Muslim, halal certification may reflectthe quality of the productsbecause halal certified products need to comply with good manufacturing practices (GMP) and good hygiene practices (GHP).Although Japanese food and beverage companies are considered as foreign investment in Malaysia, almost all (83\%) of these companies are halal certified[25].Therefore, exploring the food supply chain integration and learning the best practices from these companies appear to be aligned with the government aspiration to position Malaysia as a global halal hub.Finally, the bilateral relations between Japan and Malaysia has been gradually developed since the introduction of the "Look East Policy" in 1982. This policy is an initiative taken by the government to learn from the experiences of Japan in the nation building of Malaysia. It is well known that the remarkable development of Japan depends heavily in its labor ethics, morale and management capability.Thus, this study is an effort to further enhance the bilateral relations between Japan and Malaysia.

\subsection{Supply chain integration}

The primary objective of a supply chain is to create value in terms of quality, cost, speed and flexibility to the end customers as well as companies in the chain $[6,7,26]$.Implementing supply chain integration is one of the crucial ways to achieve this objective. An integrated supply chain may help to tie the whole network together, which could eventually help to reduce perennial supply chain challenges [27]such as poor demand management and forecasting as well as inadequate formation of customer and supplier relationships. As such, supply chain integration helps companies to integrate process activities internally as well as integrating externally with customers and suppliers [28]. The literature describes that supply chain integration may enhance the performance of the business[28, 29].Integration of supply chains could take place at both strategic and operational levels[30, 31]. The integration could be in the form of having a longterm relationship, open communications, mutual benefits and trust and shared risk and rewards [32].

There are various ways in describing the integration processes in the literature. Stevens[1] and Giménez and Ventura[33]suggest that firms first integrate internally (coordinating supply, production and distribution), and then extend the integration to its supply chain members. In a similar study, Scott and Westbrook [34] suggested three stages in achieving an integrated supply chain. The stages are: (i) the mapping stage, to analyze lead times and inventory levels throughout the supply chain, and thus indicate the current competitive advantage of the chain and potential improvements; (ii) a positioning stage, to identify opportunities for collaborative activities between chain members and (iii) a selection of action stage, to increase the 
competitiveness of the chain. Alternatively, Frohlich\& Westbrook[10] classified supply chain strategies into various types based on the different arcs of integration. They found that the widest arcs of integration had the strongest association with performance improvement.

Earlier,Stevens [1] stated that the development of an integrated supply chain requires themanagement of material flow to be viewed from three perspectives; strategic, tactical and operational. At each level, the use of facilities, people, finance and systems must be co-ordinated and harmonized as a whole. Indeed, there are so many operational and strategic facetsofintegration in supply chain management. Any given implementation can take an infinite variety of forms, progress through radically different stages, and result in several different outcomes[35].Yet, the methodologies and frameworks for effective supply chain and sustainable supply chain performance evaluation and benchmarking are not well advanced in the literature. As a consequence, there is a consensus that there is no "proven path" in implementing supply chain integration.

Globalization urged the need to implement supply chain integration becauseit may increase demand for product variety and at the same time reduce product life cycles.Supply chain integration helps solved this issue by enabling products to be designed faster without compromising the quality and costs [36] because integration helps to control the cost of production[37]. For instance, costs can be minimized through establishing consistent and predictable demand/-supply pattern[38]. In a similar vein, supply chain integration is claimed to enhance service effectiveness and improve cost efficiency [13, 39].In addition, supply chain integration is claimed to helpstrengthen the organizational competitiveness and improve customer satisfaction [40]. On the other hand,supply chain inefficiencies could waste as much as 25 percent of an organization's operating costs[35].

Although the benefits of integration has long been gazetted in the literature, there exists a significant gap between supply chain theory and practice. If supply chain integration would be a prerequisite for winning performance [41], why onlya few companies engage in extensive or advanced supply chain integration practices?[31, 42-45].This could possibly due partly to the lack of knowledge as to how integration can be implemented. Mindful of this, this study intends to reveal Japanese food supply chain integration practices in an attempt to provide further insights about this issue.

\section{RESEARCH METHOD}

Aligned with the main objective to explore the supply chain integration of Japanese food and beverage companies, a qualitative methodology is employed. Brand[46]emphasizes the value of qualitative methodology in gaining a greater understanding of the "how" and "why" of the respondents' perceptions which cannot be elicited easily from large-scale questionnaires. Furthermore, this method allows researchers to get into the depth rather than the breadth of the issue [47].

A total of ten (10) interviews with the supply chain/logistic managers working with the Japanese food and beverage companies were conducted using an open-ended interview approach. These companies were randomly selected based on Japan External Trade Organizations (JETRO) listing. The number of interviews is deemed appropriate because the interviews were conducted with people who are considered experts in the field [48]. Interviews lasted between 1 hour and 1 hour 30 minutes. Each interview was conducted by two researchers and the main researcher participated in all interviews. Interviews were tape-recorded and transcribed in their entirety. Added information was collected from secondary data sources such as company reports and other 
material that companies were willing to share. The primary and secondary data were triangulated to increase reliability and internal validity of research findings [49].

Following standard practice of qualitative research [50], the data obtained from the interviews were read reiteratively and analyzed rigorously through an inductive process of identifying the common and salient themes. The process of data analysis was aided with the use of NVivo10, a software used to analyze qualitative data. A final step in the inductive approach requires an assessment of the trustworthiness. As a means to assess validity, the other researchers independently made the coding process and compared the findings with the initial results. Should there be any observed discrepancies, the researchers collaborate to resolve the anomalies.

\section{RESULTS AND DISCUSSION}

There are 18 (Table 1) Japanese food and beverage companies representing $2.5 \%$ of total Japanese manufacturing companies in Malaysia[51]. The majority of these companies (61\%) is located in Johor and Selangorwhilst the remaining are in Kuala Lumpur, Penang and Perak (Figure 1).

A total of 10 interviews was carried out with the supply chain/logistic managers involving five randomly selected companies. All the managers have more than 10 years working experience. The designations and experiences of the managers reflect their vast knowledge and management skills in handling supply chain issues in their companies.

To reiterate, this study sought to explore food supply chain integration practices in Japanese food and beverage companies operating in Malaysia. Van Der Vorst et al. [52]describe a food supply chain as a flow of transforming agriculture or food products from the point of production to the point of consumption. Interestingly, findings indicate that all the five randomly selected companies maintain a short and simple food supply chain irrespective of company size. Childerhouse and Towill[53] affirmed the positive effect of having a simple material flow on value stream performance.

Table 1:Japanese Related Companies (Manufacturing) in Malaysia

\begin{tabular}{lc}
\multicolumn{1}{c}{ Manufacturers } & Total \\
Food \& Beverage & 18 \\
Textile \&Textile Products & 16 \\
Wood \& Wooden Products & 26 \\
Petroleum \& Chemical Products & 89 \\
Steel \& Non Ferrous Mtl. Products & 76 \\
Machinery & 25 \\
Electronic \& Electrical Products & 273 \\
Transport Mach. \& Parts & 61 \\
Other Manufacturing & 146 \\
Total Manufacturing companies & $\mathbf{7 3 0}$
\end{tabular}

Source: Jetro- information as at 18 April 2011. 


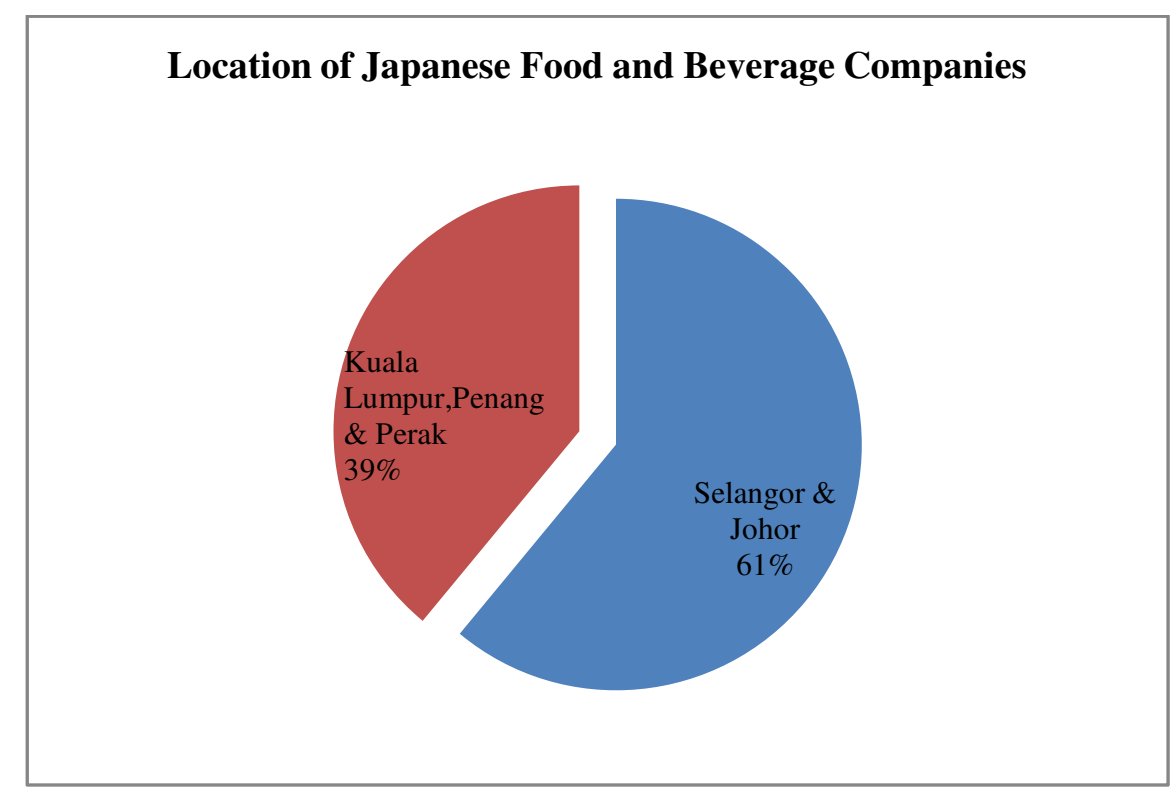

Figure 1: Location of Japanese Food and Beverage Companies in Malaysia

Figure 2 illustrates the general structure of food supply chain of the companies. The short and simple chain consists of suppliers of raw materials, food manufacturers and food retailers. The Japanese food and beverage companies act as the food manufacturers in the chain. All the managers interviewed unanimously agreed on having a short and simple food supply chain structure is the foundation of designing a time-efficient supply chain. This is explicitly expressed by the following managers;

"Before discussing about integration....having a short and simple supply chain is a must..Easy to monitor... We need to know all aspects to maintain the quality of our products." Manager 5

"We have simple procedures... from procurement till finished products... all very simple.... a fast flow”.... Manager 1

"Everything very simple... from supplier till completed product... managing the flow is the main issue" . Manager 8

Based on Figure 2, most of the raw materials $(80 \%)$ used in the production process in these companies are supplied by local suppliers. Only two companies reported to use a small portion of imported raw materials (20\%) from Indonesia and Thailand in the production of their food products. The proximity to the suppliers help in maintaining the quality of the raw materials because the raw materials are exposed to a high risk of being contaminated. For instance, failure to maintain appropriate temperature in the storage system or production process could negatively affect the product life span and trigger food safety issues[54]. 


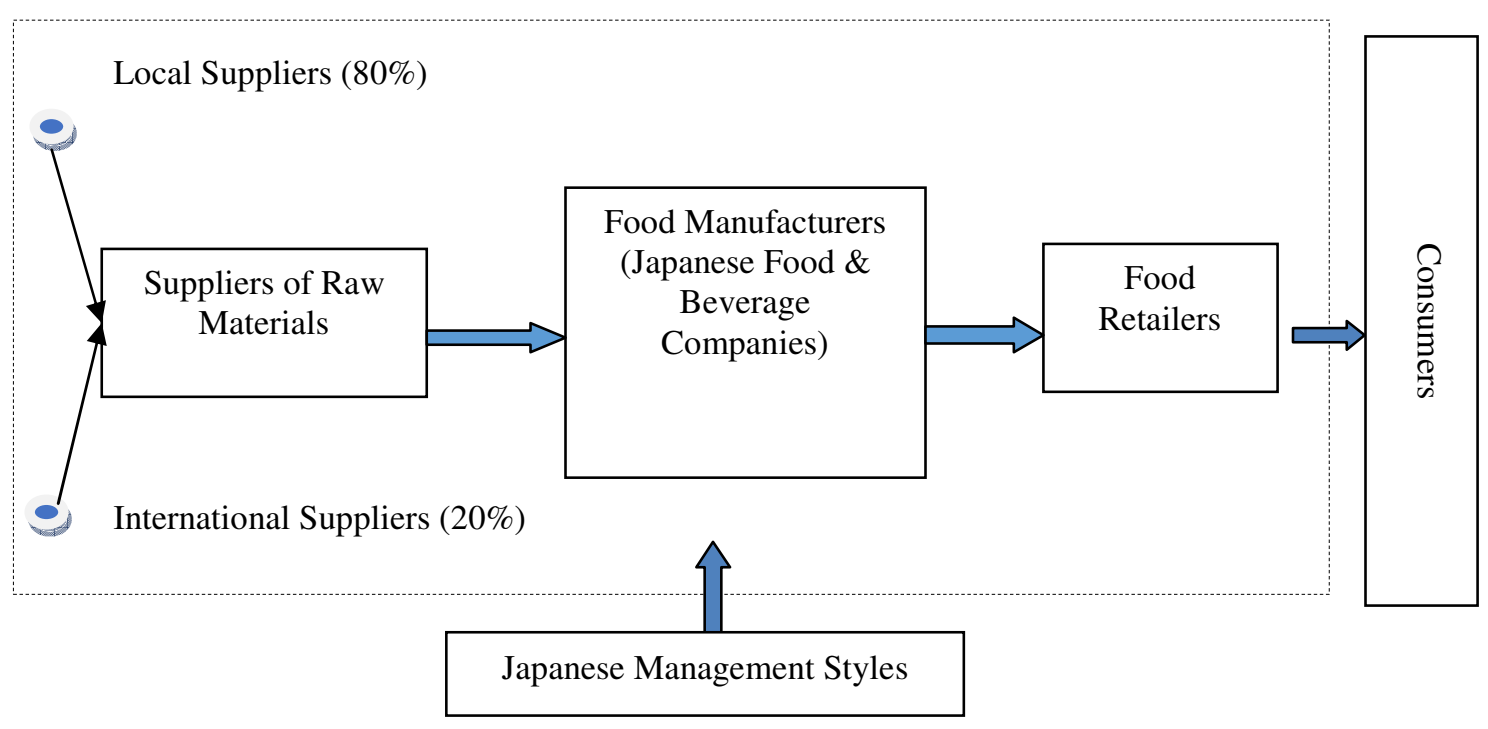

Figure 2: Japanese Food Supply Chain

Furthermore, the companies implement a functional organizational structure where employees are grouped into several functional areas such as procurement, human resource, finance, production and sales; managed through clear lines of authority and need to report to the top management. Apparently, the functional organizational structure enforces a clear chain of command with the company's top level management and encourage information sharing across the company as well as with external parties of the supply chain such as suppliers of raw material and food retailers. Earlier, information sharing is claimed as a critical element in the supply chain integration [55] because it serves as a platform through which all parties in the chain can engage in coordination, joint action and problem solving activities[56]. In short, the functional organizational structure helps in managing the supply chain by allowing a seamless flow of goods as well as information through the chain. Both elements (goods and information) are posited to be equally important in integrating the supply chain $[56,57]$.

As the food manufacturer, the companies will process raw materials from suppliers to produce a higher value added product. For example, spices such as black pepper, coriander and cinnamon are transformed into chicken seasoning. Skilled workers were employed and advanced food manufacturing technology was applied to help ensure a smooth production process. These findings resonate with those of Mohamed Arshad, Mohamed and Latiff[58], which states that biotechnology and other food production technology are often applied during the food manufacturing process in order to produce quality products which meet customer preferences.

The final actor in the chain is the food retailers that help market the finished products to the endconsumers.Aligning with the description given byTrienekens et al. [59], this chain level concerned with the distribution of finished products. Cartons of food products were unloaded at the warehouse and reloaded onto a truck. Some of the food products need to be kept in the cold storage in order to maintain the quality. As such, most of the warehouses and trucks are equipped with the cold room or storage.

When reflecting about supply chain integration, almost all of the managers admitted their companies have a high level of integration with the suppliers of raw materials. The companies 
purposely have only a few numbers of selected suppliers of raw materials to ease them in maintaining close relationships. Earlier, Jantan et al. [71] posit proper selection and management of the right suppliers may help the company to leverage its competencies and capabilities which could eventually refine its supply chain flexibility. In fact, these companies could be considered to have reached a "full information sharing" level with their suppliers. At this level, the suppliers not only receive actual orders from the companies, but also furnish with other information such as production status, transportation availability and demand data[60]. This is quite an achievement because information sharing is often claimed to be a generic cure for supply chain ailments [61, 62].

Another interesting fact is that almost all companies do not have any official contract with their suppliers. To quote one of the interviewees (Manager 2), " no signed contract... mutual agreement. we have been working with some for about 16 years"; this signifies that the companies do not have any official contract and have successfully managed to establish a long term relationship with their suppliers based on mutual agreement. Although the companies appear to unanimously agree with the argument made by Batt[63]that a long term business relationship may repress market uncertainties, but not be good enough to provide price certainty, they seem to be in control regarding the price of raw materials as disclosed by one of the interviewees (Manager 6) " no doubt price hike is our problem...but so far we managed to come into terms with our suppliers".

The companies are extremely interfaced with their suppliers through various methods. Some of the companies placed the order of raw materials through phone and others placed the order by emailing relevant forms to the suppliers. Regardless of ordering methods, all companies admit to having daily telephone communication with their suppliers. In addition, they will have meetings with the suppliers whenever necessary. On the other hand, suppliers sometimes invite them to attend seminars to explain about new technologies or to introduce them with new raw materials which might be useful in manufacturing their finished products. According to Stock et al. [64], frequent communication andthe cooperative efforts between the companies and their suppliers may provide an indication of having a high level of integration. All these integrative efforts are done to establish mutual understanding in doing business with each other. Once this is established, managing suppliers and ensuringthe correct quantity and quality of raw materials were delivered to them are no longer a major problem for the companies. This is explicitly articulated by these managers;

“We communicate with them daily... phone, emails... very important to update them with what we want"................... Manager 10

"So far no problem... they understand what we want... if they don't, they will contact us and clarify”..... Manager 7

" Raw material is very important... the quality... the suppliers know, we always communicate with them..almost daily”.............Manager 4

"Sometimes we need new ingredients (raw materials)... they have new technologies... they invite us to their seminars".............. Manager 9

All companies appear to be seriously concerned about coordinating and integrating cross functional processes within their companies; indicating the existence of internal integration [65]. They rely heavily on their information technology (IT) facilities to share key information across the departments in their companies. The main purpose is to achieve real-time transmission in 
processing information throughout the supply chain [56]. In a way, information sharing could help expedite and ensure accuracy in supply chain decision making, such as lowering costs through reductions in inventories and shortages [66].For instance, one of the managers consistently highlighted

"Weare operating in a fully (80\%) computerized environment... we used the SAP system to manage our inventory... we also have computerized system to help monitor our production process" Manager 1

Proper planning and accuracy in forecasting are the two important elements in ensuring a seamless flow of material across the departments within the companies. The production planning department plays an important role in coordinating information from various departments. All companies do their yearly planning and some of the companies even have a monthly production plan. Meetings among the departmental managers to discuss arising issues could be considered as common daily events. On top of that, the departmental managers will have monthly meetings with the director.

Again, information technology (IT) back up the daily operations of the companies as well as facilitates the alignment of forecasting and allows better inter-departments coordination. Previous studies show that effective IT connection, improves the integration level of supply chain in terms of material flow [67] and support key processes in the chain such as procurement and order fulfillment $[68,69]$.

Another common type of integration described in the literature is the forward integration, which involves coordination between the food manufacturer and its downstream chain members[10, 65]. All the managers interviewed reveal their companies have moderate level of integration with the end-consumers and retailers as compared to the suppliers. The primary reason is because most of the companies are having their affiliatecompanies act as their retailers and a few have a joint venture agreements with Malaysian companies to market their products. Therefore, the retailers and not the companies that deal directly and have close relationships with the end-consumers or customers.

Affirming the significant influence of retailers-consumers relationship, Cox and Mowatt[70] posit that there are cases where some retailers may have greater power relative to the manufacturer and are able to coerce and coordinate the chain through their control over consumer information. Surprisingly, this is not an issue of concern for all companies in this study because they are confident with the commitment given by the retailers to market their food products accordingly. In fact, all of the companies are very confident of having their loyal customers. Nevertheless, all the managers interviewed agreed to the fact that providing a good logistics system supported by advanced technology play an important role in ensuring quality food products are received by the retailers and consequently reached the end-consumers. These issues were confirmed by the following statements;

“We are not worried too much about marketing... we have joint venture agreements"............................................Manager 9

“Most of the times we supply our products to our affiliates”...Manager 2

"So far we do not have problems selling our products. The customers are there... maintaining the quality is the focus".................Manager 6 
International Journal of Managing Value and Supply Chains (IJMVSC) Vol. 6, No. 4, December 2015

"Of course the logistics and technology help us a lot... we need an efficient logistics system to transfer our products and...yes... advanced technology help maintaining the quality". Manager 3

In addition to the integration practices, it is apparent that organizational culture, more specifically the Japanese management styles support the food supply chain operation in these companies. Although the companies operate in Malaysia and the majority of employees are Malaysian, they seem to practice Japanese management styles. For instance, policies often originate from the middle-levels of a company before submitting to the top management for ratification. As such, the implementation of the policies will be easier because the person in charge is involve in the shaping of such policies.

Inevitably, managers have a close relationship with their subordinates. Teamwork is the norms in these companies. Subordinates need to keep the managers fully informed of development and in return the managers must ensure that they are easily accessible at all times. This reciprocity relationship forms the basis of teamwork as well as helping to subside few internal managerial conflicts such as the problem of miscommunication and resistance to change among employees.

Some of the companies have small group meetings, whereby small groups of employees meet once a week, on a scheduled basis, to discuss their functions and problems they encounter. This practice provides a means for employees to be involved in the company affairs and at the same time, management would benefit from suggestions given by the employees. Indeed, employees' suggestions play an important role in these companies as one manager said,

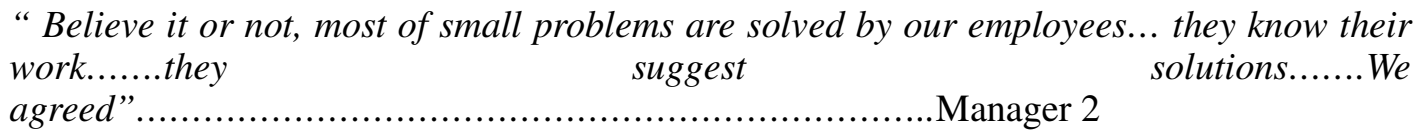

Moreover, the Japanese management style provides opportunities for employees to expand their job boundaries. The working environment is more like a supportive learning environment for the employees. As a result, the only critical turnover problem is among the production operators. Other levels of employees appear to be happy with their position and enjoy the working environment. A few of the companies have employees who have been working for them for more than 20 years, as claimed by one of the managers,

“We have problems with the production operators... now we hire foreigners... still have problems... others are happy... there are few chaps who have been working for us for more than 20 years". Manager 10

Obviously, Just in Time (JIT) manufacturing philosophy is applied by these companies in ensuring of having effective and efficient working environment. The basic idea of JIT is to produce the food products to meet customer demand exactly, in time, quality and quantity. This philosophy helps companies to gain competitive advantage specifically by reducing wastes and improving product quality and efficiency of production. In addition, these companies seriously practices the $5 \mathrm{~S}$ (seiri, seiton, seiso, seiketsu and shitsuke) organization method. This method helps to organize a work space in a clean, efficient and safe manner which eventually could enhance productivity, visual management and ensure standardized operational practices. 
International Journal of Managing Value and Supply Chains (IJMVSC) Vol. 6, No. 4, December 2015

\section{CONCLUSION}

This study has successfully revealed the food supply chain integration practices in Japanese food and beverage companies operating in Malaysia. In doing so, it has drawn attention to the three important aspects of the Japanese food supply chain. First, a short and simple structure is used as the platform of the supply chain. Secondly, the food supply chain could be considered as highly integrated, although the degree of integration differs throughout the network. According to Lambert and Cooper [32], integrated supply chains are characterized by long term relationships, open communication, mutual benefits and trust as well as shared risk and rewards among the parties in the network. In addition, the three types of integration commonly described in the supply chain literature seem to be applied by these companies. Finally, the Japanese management styles is the pivotal supporting element in managing and sustaining the integrated food supply chain in these companies. These findings may act as a valuable input to other food manufacturers operating in Malaysia because the Japanese unique supply chain assessment and managementpractices is proven to be a source in sustaining global competitiveness [72].

\section{ACKNOWLEDGMENT}

The authors would like to thank The Sumitomo Foundation for granting the research grant (Grant for Japan-related Research Projects). However, all the contents in this paper are of the authors' responsibilities.

\section{REFERENCES}

1. G. C. Stevens, "Integrating the supply chain," International Journal of Physical Distribution \& Material Management, vol. 19, pp. 3-8, 1989.

2. R. Alfalfa-Luque, C. Madina-Lopez, and P. Kumar-Dey, "Supply chain integration framework using literature review," Production, Planning and Control, vol. 1, pp. 1-18, 2012.

3. M. Christopher, Logistics and supply chain management, 3rd ed. London: FT Prentice Hall, 2005.

4. B. B. Flynn, B. Huo, and X. Zhao, "The impact of supply chain integration on performance: A contingency and configuration approach," Journal of Operations Management, vol. 28, pp. 58-71, 2010.

5. D. J. Bowersox, D. J. Closs, and T. P. Stank, 21st century logistics: making supply chain integration a reality: Council of Logistics Management, 1999.

6. D. Walters and G. Lancaster, "Value and information-concepts and issues for management," Management Decision, vol. 37, pp. 643-656, 1999.

7. J. D. Wisner, G. K. Leong, and K.-C. Tan, Principles of supply chain management: A balanced approach. Ohio: Thomson South-Western, 2005.

8. R. Ganeshan and T. P. Harrison, An introduction to supply chain management. Pennsylvania: Department of Management Sciences and Information Systems,Penn State University, 1995.

9. J. T. Mentzer and K. B. Kahn, "A framework of logistic research," Journal of Business Logistics, vol. 16, pp. 231-250, 1995.

10. M. Frohlich and R. Westbrook, "Arcs of integration: An international study of supply chain strategies," Journal of Operations Management, vol. 19, pp. 185-200, 2001.

11. T. M. Simatupang and R. Sridharan, "Benchmarking supply chain collaboration: An empirical study," Benchmarking: An International Journal, vol. 11, 2004.

12. S. Mohezar Ali, "Information technology (IT) integration in supply chain operations: An empirical study of the Malaysian food industry," Doctor of Philosophy, School of Management, University of South Australia, 2011.

13. R. Narasimhan and S. W. Kim, "Information system utilization strategy for supply chain integration," Journal of Business Logistics, vol. 22, pp. 51-75, 2001. 
International Journal of Managing Value and Supply Chains (IJMVSC) Vol. 6, No. 4, December 2015

14. A. G. Bruzzone, F. Longo, M. Massei, L. Nicoletti, and M. Agresta, "Safety and security in fresh food supply chain," International Journal of Food Engineering, vol. 10, pp. 545-556, 2014.

15. P. Childerhouse and D. R. Towill, "Arcs of supply chain integration," International Journal of Production Research, vol. 49, pp. 7441-7468, 2011.

16. M. Inagaki and K. Kuroda. (2007, 14 April 2015). Global Focus: Supply Chain Management in Japan.Available:http://www.sdcexec.com/article/10289786/global-focus-supply-chainmanagement-in-japan

17. E. B. Mc Cullough, P. L. Pingali, and K. G. Stamoulis, Small farms and the transformation of food systems: An overview. London: Earthscan, 2008.

18. J. Jogwanich and Magtibay-Ramos, "Determinants of structural changes of food exports from developing countries," ed. Manilla, Philipines: Asian Development Bank, 2009.

19. Malaysian Development Investment Authority. (Undated). Food Industry in Malaysia. Available: http://www.mida.gov.my/home/administrator/system_files/modules/photo/uploads/201402141427 41_Food_V1.pdf

20. NZTE. (2014, 16 April 2015). Food and beverage market in Malaysia. Available: https://www.nzte.govt.nz/en/export/market-research/food-and-beverage/food-and-beveragemarket-in-malaysia/

21. MITI, "Third Industrial Master Plan," M. M. o. I. T. a. Industry, Ed., ed. Malaysia, 2006.

22. ETP, "The Economic Transformation Programme: a roadmap for Malaysia ", P. M. s. Department, Ed., ed. Putrajaya, 2010.

23. A. Agus and M. S. Hajinoor, "Lean production supply chain management as driver towards enhancing product quality and business performance: Case study of manufacturing companies in Malaysia," International Journal of Quality \& Reliability Management, vol. 29, pp. 92-121, 2012.

24. N. M. Nik Muhammad, F. Md Isa, and B. Chee Kifli, "Positioning Malaysia as halal-hub: Integration role of supply chain strategy and halal assurance system," Asian Social Science, vol. 5, pp. 44-52, 2009.

25. M. N. Md Akhir, Y. Ishii, R. Paidi, A. Hassan, M. I. Mohd Huda, S. R. Kassim, et al., "Japanese halal food production in Malaysia: a prospective study," International Journal of East Asian Studies, vol. 1, pp. 25-35, 2011.

26. W. S. Chow, C. N. Madu, C.-H. Kuei, M. H. Lu, C. Lin, and H. Tseng, "Supply Chain Management in the US and Taiwan: An Empirical Study," Omega: The International Journal of Management Science, vol. 36, pp. 665-679, 2008.

27. J. Storey, C. Emberson, J. Godsell, and A. Harrison, "Supply Chain Management: Theory, Practice and Future Challenges," International Journal of Operations \& Production Management, vol. 26, pp. 754-774, 2006.

28. D. M. Lambert, M. C. Cooper, and J. D. Pagh, "Supply chain management implementation issues and research opportunities," The International Journal of Logistics Management, vol. 11, pp. 1-17, 1998.

29. A. Lau, E. Tang, and R. Yam, "Effects of supplier and customer integration on product innovation and performance: empirical evidence in Hong Kong manufacturers," Journal of Product Innovation Management, vol. 27, pp. 761-777, 2010.

30. J. T. Mentzer, W. Dewitt, and J. S. Keebler, "Defining Supply Chain Management," Journal of Business Logistics, vol. 22, pp. 1-25, 2001.

31. S. Zailani and P. Rajagopal, "Supply chain integration and performance: US versus East Asian companies. ," Supply Chain Management: An International Journal, vol. 10, pp. 379-393, 2005.

32. D. M. Lambert and M. C. Cooper, "Issues in supply chain management," Industrial Marketing Management, vol. 29, pp. 65-83, 2000.

33. C. Gimenez and E. Ventura, "Logistics-production, logistics-marketing and external integrationtheir impact on performance," International Journal of Operations and Production Management, vol. 25, pp. 20-38, 2005.

34. C. Scott and R. Westbrook, "New strategic tools for supply chain management," International Journal of Physical Distribution \& Logistics Management, vol. 21, pp. 23-33, 1991.

35. MAC., "Implementing integrated supply chain management for competitive advantage," Institute of Management Accountants, New Jersey, USA,1999. 
36. A. Ajmera and J. Cook, "A multi-phase framework for supply chain integration," Advanced Management Journal, vol. 74, pp. 37-47, 2009.

37. R. M. Sundaram and S. G. Mehta, "A comparative study of three SCM approaches.," International Journal of Physical Distribution \& Logistics Management, vol. 32, pp. 532-555, 2002.

38. R. Sabath and J. M. Whipple, "Using the customer/product action matrix to enhance internal collaboration," Journal of Business Logistics, vol. 25, pp. 1-19, 2004.

39. R. G. Richey, A. S. Roath, J. M. Whipple, and S. E. Fawcett, "Exploring a governance theory of supply chain management: barriers and facilitators to integration," Journal of Business Logistics, vol. 31, pp. 237-256, 2010.

40. F. Talib, Z. Rahman, and M. N. Qureshi, "Integrating total quality management and supply chain management: similarities and benefits," The IUP Journal of Supply Chain Management, vol. 7, pp. 26-44, 2011.

41. H. Lee, "Creating value through supply chain integration," Supply Chain Management Review, vol. September, pp. 30-36, 2000.

42. H. Akkermans, P. Bogerd, and B. Vos, "Virtuous and vicious cycles on the road towards international supply chain management," International Journal of Operations \& Production Management, vol. 19, pp. 565-582, 1999.

43. F. Bakker, T. Boehme, and D. P. Donk, "Identifying barriers to internal supply chain integration using systems thinking," presented at the The 4th Production and Operations Management World Conference, Amsterdam, 2012.

44. A. Halldorsson, P. D. Larson, and R. F. Poist, "Supply chain management: a comparison of Scandinavian and American perspectives," International Journal of Physical Distribution \&Logistics Management, vol. 38, pp. 126-142, 2008.

45. D. R. Towill, P. Childerhouse, and S. M. Disney, "Integrating the automotive supply chain: where are we now?," International Journal Physical Distribution \& Logistics Management, vol. 32, pp. 79-95, 2002.

46. V. Brand, "Empirical business ethics research and paradigm analysis.," Journal of Business Ethics, vol. 86, pp. 429-449, 2009.

47. J. D. Daniels and M. V. Cannice, "Interview studies in international business research," in Handbook of Qualitative Research Methods For International Business, R. Marschan-Piekkari and C. Welch, Eds., ed Cheltenham, UK: Edward Elgar, 2004, pp. 185-206.

48. C. Glesne, Becoming Qualitative Researchers, 2nd ed. New York: Longman, 1999.

49. R. K. Yin, Case study research: design and methods (applied social research methods), Fifth ed. Thousand Oaks, California: Sage Publications, 2013.

50. M. B. Miles and A. M. Huberman, Qualitative data analysis: An expanded sourcebook. Thousand Oaks, CA: Sage, 1994.

51. JETRO. Apri12014). Available:http://www.jetro.go.jp/malaysia/services/jpncoinmsia/index.html/JRC_Statistic.pdf

52. J. Van Der Vorst, S. Van Dongen, S. Nougier, and R. Hihorst, "E-business initiatives in food supply chain: definition and typology of electronic business models," International Journal of Logistics: Research \& Applications, vol. 5, pp. 119-138, 2002.

53. P. Childerhouse and D. R. Towill, "Analysis of the factors affecting the real-world value stream performance," International Journal of Production Research, vol. 40, pp. 3499-3518, 2002.

54. T. Kelepouris, K. Pramatari, and G. Doukidis, "RFID-enabled traceability in the food supply chain," Industrial Management and Data Systems, vol. 107, pp. 183-200, 2007.

55. C. W. Lee, I.-W. G. Kwon, and D. Severance, "Relationship between supply chain performance and degree of linkage among supplier, internal integration, and customer," Supply Chain Management: An International Journal, vol. 12, pp. 444-452, 2007.

56. D. Prajogo and J. Olhager, "Supply chain integration and performance: the effect of long-term relationship, informaton technology and sharing, and logistics integration," International Journal of Production Economics, vol. 135, pp. 514-522, 2012.

57. D. Power, "Supply chain management integration and implementation: a literature review," Supply Chain Management: An International Journal, vol. 10, pp. 252-263, 2005.

58. F. Mohamed Arshad, Z. Mohamed, and I. A. Latiff, "Changes in agri-food supply chain in 
International Journal of Managing Value and Supply Chains (IJMVSC) Vol. 6, No. 4, December 2015

Malaysia: implications on marketing need," in FAO/AFMA/FAMA Regional Workshop on Agricultural Marketing Training, Kuala Lumpur, 2006, pp. 331-348.

59. J. H. Trienekens, R. V. Uffelen, J. Debaire, and O. Omta, "An assessment of innovation and performance in the fruit chain: The innovation-performance matrix," British Food Journal, vol. 110, pp. 98-127, 2008.

60. F. Sahin and E. P. Robinson, "Flow coordination and information sharing in supply chains: review, implications, and direction for future research," Decision Sciences, vol. 33, pp. 505-535, 2002.

61. F. Chen, Z. Drezner, J. K. Ryan, and D. Simchi-Levi, "Quantifying the bull-whip effect in a simple supply chain: the impact of forecasting, lead times, and information," Management Science, vol. 46, pp. 436-443, 2000.

62. D. Simchi-Levi, P. Kaminsky, and E. Simchi-Levi, Designing and managing the supply chain. New York: Irwin McGraw-Hill, 2000.

63. P. J. Batt, "Incorporating measures of satisfaction, trust and power-dependence into an analysis of agribusiness supply chains," in Agriproduct supply-chain management in developing countries, Canberra, 2004, pp. 27-43.

64. G. N. Stock, N. P. Greis, and J. D. Kasarda, "Enterprise logistics and supply chain structure: the role of fit," Journal of Operations Management, vol. 18, pp. 531-547, 2000.

65. S. E. Fawcett and G. M. Magnan, "The rhetoric and reality of supply chain integration," International Journal of Physical Distribution \& Logistics Management, vol. 32, pp. 339-361, 2002.

66. H. I. Lee, K. C. So, and C. S. Tang, "The value of information sharing in a two level supply chain," Management Science, vol. 46, pp. 626-643, 2000.

67. F. Soliman and M. Youssef, "The impact of some recent developments in e-business on the management of next generation manufacturing," International Journal of Operations and Production Management, vol. 21, pp. 538-564, 2001.

68. D. F. Kehoe and N. J. Boughton, "New paradigms in planning and control across manufacturing supply chains," International Journal of Operations and Production Management, vol. 21, pp. 582593, 2001.

69. J. M. Swaminathan and S. R. Tayur, "Models for supply chains in E-business," Management Science, vol. 49, pp. 1387-1406, 2003.

70. H. Cox and S. Mowatt, "Consumer-driven innovation networks and e-business management systems," Qualitative Market Research: An International Journal, vol. 7, pp. 9-19, 2004.

71. M.Jantan, N.O. Ndubisi, and L.C. Hing, "Supplier selection strategy and manufacturing flexibility: impact of quality and technology roadmaps," Asian Academy of Management Journal, vol. 11,issue 1, pp. 19-47, 2006.

72. J.Henke and C.Zhang, "Increasing supplier-driven innovation,"MIT Sloan Management Review, vol. 51, issue 2 pp. 41-46, 2010.

\begin{abstract}
Authors
IntanMarzitaSaidonis a senior lecturer in the Faculty of Accountancy at the UniversitiTeknologi MARA (UiTM),Kedah, Malaysia. She has more than twenty years experience teaching various accounting courses in UiTM. She obtained her first degree from NorthumbriaUniversity, United Kingdom and holds a Ph.D degree from Curtin University, Australia. She is an associate member ofMalaysian Institute of Accountants. Her present research interests include ethics, strategic management and accounting education.
\end{abstract}

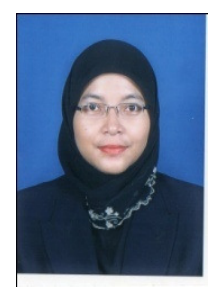


International Journal of Managing Value and Supply Chains (IJMVSC) Vol. 6, No. 4, December 2015

Rafisah Mat Radzi is a senior lecturer at the School of Distance Education, UniversitiSains Malaysia. Previously, she was a lecturer in the Faculty of Business Management of the UniversitiTeknologi Mara (UiTM), Perlis, Malaysia. She received her Bachelor of Business Administration (majoring in Finance) from UniversitiKebangsaan Malaysia and Master of Science in Finance from Universiti Utara Malaysia. She obtained her $\mathrm{PhD}$ in Business and Management from the University of South Australia. Rafisah's research and teaching interests encompass the areas of Islamic banking and finance.

Nadzri Ab Ghani is a senior lecturer in the Faculty of Accountancy at UniversitiTeknologi MARA (UiTM), Kedah, Malaysia. He has been with UiTM for thirteen years and before joining UiTM he was a lecturer at InstitutTeknologiTun Abdul Razak, Malaysia. He holds a Ph.D in Corporate Governance (specifically in the area of whistle-blowing) from Curtin University, Australia. He is an active researcher and his research interests include whistle-blowing, supply chain management and accounting education.
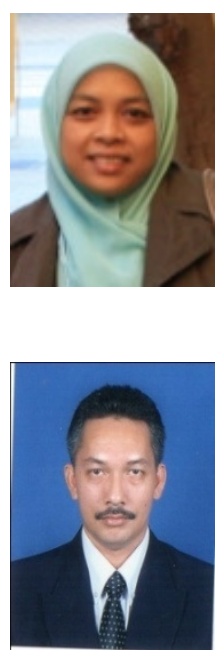